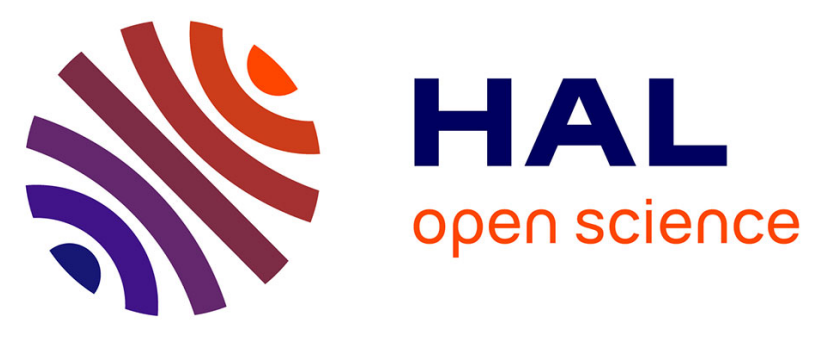

\title{
Do spawn storage conditions influence the colonization capacity of a wheat-straw-based substrate by Agaricus subrufescens?
}

\author{
Anne Marie Farnet da Silva, Leila Qasemian, Frédérique Peter-Valence, \\ Florence Ruaudel, Jean-Michel Savoie, Sevastianos Roussos, Isabelle \\ Gaime-Perraud, Fabio Ziarelli, Elisée Ferré
}

\section{To cite this version:}

Anne Marie Farnet da Silva, Leila Qasemian, Frédérique Peter-Valence, Florence Ruaudel, Jean-Michel Savoie, et al.. Do spawn storage conditions influence the colonization capacity of a wheat-strawbased substrate by Agaricus subrufescens?. Comptes Rendus Biologies, 2014, 337 (7-8), pp.443-450. 10.1016/j.crvi.2014.06.002 . hal-02071802

\section{HAL Id: hal-02071802 https://hal.science/hal-02071802}

Submitted on 18 Mar 2019

HAL is a multi-disciplinary open access archive for the deposit and dissemination of scientific research documents, whether they are published or not. The documents may come from teaching and research institutions in France or abroad, or from public or private research centers.
L'archive ouverte pluridisciplinaire HAL, est destinée au dépôt et à la diffusion de documents scientifiques de niveau recherche, publiés ou non, émanant des établissements d'enseignement et de recherche français ou étrangers, des laboratoires publics ou privés. 


\title{
Do spawn storage conditions influence the colonization capacity of a wheat-straw-based substrate by Agaricus subrufescens?
}

\section{Les conditions de stockage du blanc influencent-elles le potentiel de colonisation d'un substrat à base de paille de blé par Agaricus subrufescens?}

\author{
Anne-Marie Farnet ${ }^{\mathrm{a}, *}$, Leila Qasemian ${ }^{\mathrm{a}}$, Frédérique Peter-Valence ${ }^{\mathrm{a}}$, \\ Florence Ruaudel ${ }^{\mathrm{a}}$, Jean-Michel Savoie ${ }^{\mathrm{b}}$, Sevastianos Roussos ${ }^{\mathrm{a}}$, \\ Isabelle Gaime-Perraud ${ }^{a}$, Fabio Ziarelli $^{c}$, Élisée Ferré ${ }^{\mathrm{a}}$ \\ a Institut méditerranéen de biodiversité et d'écologie marine et continentale (IMBE), Aix Marseille université, UMR CNRS, IRD, \\ Avignon université, faculté de Saint-Jérôme, 13397 Marseille cedex 20, France \\ b INRA, UR 1264 MycSA, Mycologie et sécurité des aliments, BP 81, 33883 Villenave-d'Ornon, France \\ ${ }^{\mathrm{c}}$ TRACES, Campus de l'Étoile, 13397, Aix-Marseille université, Marseille cedex 20, France
}

Mots clés :

Champignon amande Enzymes lignocellulolytiques

Culture de champignons

RMN du solide du ${ }^{13} \mathrm{C}$

\begin{abstract}
A B S T R A C T
Storage conditions of the spawn of edible fungi are of major importance to facilitate the production of mushrooms. Here, standard storage conditions at $10^{\circ} \mathrm{C}$ or $15^{\circ} \mathrm{C}$ were used and the potential of colonization of standard European compost by the tropical species Agaricus subrufescens was assessed during the spawn running phase. Two lignocellulolytic activities, laccase and CMC-cellulase, were enhanced after storage compared to control as well as substrate transformation, as described by the aromaticity ratio and a humification ratio calculated from NMR data. This result indicates that mycelium growth probably occurred during storage at 10 or $15{ }^{\circ} \mathrm{C}$, leading to a larger amount of biomass in the inoculum. Moreover, the microbial functional diversity of the substrate was favored, showing that the electivity of the substrate was maintained. Thus, these findings indicate that recommendations for the mushroom producers can be established for $A$. subrufescens cultivation under European standard conditions.
\end{abstract}

R É S U M É

Les conditions de stockage du blanc des champignons comestibles sont de première importance pour faciliter la production de champignons. Ici, des conditions standard de stockage à 10 et $15^{\circ} \mathrm{C}$ ont été utilisées et le potentiel de colonisation d'un compost européen classique par l'espèce tropicale Agaricus subrufescens a été estimé durant la phase de colonisation du blanc. Les activités lignocellulolytiques laccase et CMC-cellulase ont été

\footnotetext{
* Corresponding author.

E-mail address: anne-marie.farnet@imbe.fr (A.-M. Farnet).
} 
activées après stockage en comparaison avec le contrôle ainsi que la transformation du substrat, comme décrit par les ratios d'aromaticité et d'humification calculés à partir des données de RMN. Ce résultat indique qu'une croissance mycélienne a probablement eu lieu durant la période de stockage à 10 ou $15^{\circ} \mathrm{C}$, conduisant à une plus grande quantité de biomasse dans l'inoculum. De plus, la diversité fonctionnelle microbienne du substrat a été favorisée, montrant que l'électivité du substrat était maintenue. Ainsi, ces recherches indiquent que des recommandations auprès des producteurs de champignons peuvent être formulées pour la culture d'Agaricus subrufescens dans les conditions standard utilisées en Europe.

\section{Introduction}

Mushroom cultivation is an important biotechnological process that combines the production of nutraceuticals with organoleptic and potentially medicinal properties using a biotechnological process that recycles agricultural by-products. For all these reasons, the production of Agaricus species has been widely developed and, in European countries, the button mushroom $A$. bisporus is the main cultivated species.

However, an emerging Agaricus species, A. subrufescens Peck, also named A. blazei Murrill sensu Heinemann, A. rufotegulis Nauta or A. brasiliensis Wasser, M. Didukh, Amazonas \& Stamets [1], is actively cultivated in Brazil since the early 1990s, first in the Sao Paolo State and then extended to other regions close to the Atlantic coast. It had become an important export production for this country. This species exhibits an almond flavor probably because of benzaldehyde and benzyl alcohol [2], which can be of great value as foods or food flavoring materials. Moreover, edible mushrooms are known to have bioactive compounds in their biomass, such as polysaccharides with anti-cancer or tumor suppressive activity, and extracts from the basidiocarp of this species have been shown to reduce tumor size in rats [3].

Interestingly, A. subrufescens can be cultivated on composts originally made for the cultivation of the button mushroom [4]. The inoculum used for the culture in compost is made of mycelium grown under sterile conditions on cereal grains and is known as the spawn. The type of material used for the spawn (wheat, rye or millet grains...) and its preparation have already been described as a crucial parameter in mushroom cultivation [5]. During this key step, the fungus fully colonizes the solid carrier chosen, starts to produce lignocellulolytic enzymes and thus fungal biomass is obtained in large amount to further inoculate the culture substrate $[6,7]$. The spawn is generally produced by specific companies and sent to mushroom growers, which implies their storage for several weeks before use. Unfortunately, A. subrufescens suffers damage when it is exposed for prolonged periods at temperatures of $4{ }^{\circ} \mathrm{C}$ or lower [1], showing a decrease in growth ability because of precocious ageing [8]. Consequently, mushroom growers have difficulties in maintaining spawn under refrigeration for long-time periods without loss of mycelium viability and spawn makers recommend to store it at temperatures around $12^{\circ} \mathrm{C}$. However, there is no information on the consequences of storage at these temperatures on the quality of the spawn and the further ability of mycelium to colonize wheatstraw-based substrates. In order to thoroughly define the process, which could be recommended for its cultivation, we investigated whether spawn of $A$. subrufescens produced on rye seeds stored at 10 or $15^{\circ} \mathrm{C}$ for 15 or 30 days was affected in its substrate-colonizing potential of horse manure and wheat-straw-based compost. The hypothesis that sustains this work is that $A$. subrufescens has a threshold of tolerance for storage conditions defined via both temperature and time of storage. The substrate-colonizing potential of six strains after different storage conditions was tested using microbiological and chemical markers: both laccase and cellulase activities, which are the main extracellular enzymes responsible for the transformation of the lignocellulosic material, and the chemical characterization of the substrate using ${ }^{13} \mathrm{C}$ solid-state NMR spectroscopy, which give information about the dynamics of this biological transformation. Moreover, the functional diversity of bacterial communities of the compost using catabolic level physiological profile(CLPP) was investigated, since this microbial part of the substrate is essential for mushroom production under solid-state fermentation conditions. It is thus important to focus on substrate microbial communities since they are involved in both substrate transformation and selectivity. We also included in this study an A. bisporus strain commonly cultivated in France as control of substrate colonization.

\section{Material and methods}

\subsection{The fungal strains}

Six strains of Agaricus spp. from the Collection of germplasms of Agaricus in Bordeaux (CGAB), INRA were used: strains CA454, CA560, CA572, CA646 and CA647 for A. subrufescens and one strain Bs527 for A. bisporus. CA454 is a subculture of the collection strain WC837 in PSUMCC registered as A. blazei and assumed to be similar to ATCC 76739, which is claimed to be a copy of the original strain cultivated for the first time in Brazil in the 1960s. CA646 and CA647 are two cultivars sold in Europe by Mycelia (Belgium) under the reference numbers 7700 and 7703 , respectively. CA560 was isolated in Botucatu, Brazil (1999) from a commercial farm and CA572 is a Brazilian cultivar purchased by D.C. Zied in 2007; both strains have proved to be genetically different [9]. Their original reference numbers are ABL-99/28 and ABL-07/58, respectively, in the Culture Collection of the Edible and Medicinal 
Mushroom Module of São Paulo State University (UNESP). An A. bisporus strain, Bs527, for which storage is commonly performed at $2-4{ }^{\circ} \mathrm{C}$, was used as control. Bs527 was a copy of the cultivar 30A (Euromycel) placed in the CGAB in 1997.

\subsection{Mesocosm experimental set-up}

Precultures were performed in glass Petri dishes containing $12 \mathrm{~g}$ dry weight of cooked and coated rye grains (spawn substrate used by spawn makers, provided by Somycel, Langeais, France) inoculated with 6 plugs $(1 \mathrm{~cm} \times 1 \mathrm{~cm})$ of malt agar cultures. They were incubated in a climatic chamber at $25{ }^{\circ} \mathrm{C}$ and $90 \% \mathrm{RH}$ (relative humidity) for 15 days. Then, to evaluate the effect of two factors i.e. time ( 15 or 30 days), and temperature ( 10 or $15 \mathrm{C}$ ) of storage, these precultures were incubated in a climatic chamber either at $10^{\circ} \mathrm{C}$ or $15^{\circ} \mathrm{C}$ for 15 or 30 days and were used immediately after storage to inoculate the mesocosms. For controls, the precultures were directly used to inoculate the mesocosms. These mesocosms were prepared with $450 \mathrm{~g}$ of fresh mushroom compost ( $135 \mathrm{~g}$ dry weight) placed in a 2-L glass pot in order to obtain a final volume of compost of $20 \mathrm{~cm} \times 16 \mathrm{~cm} \times 6 \mathrm{~cm}$ (length $\times$ width $\times$ height). They were inoculated with $3 \%$ $(w / w)$ of rye grains (dry weight), which were thoroughly mixed with the compost under aseptic conditions. The compost was commercial compost produced by SARL Renaud et Fils at Avy, France, for the cultivation of A. bisporus. The main raw materials used were horse manure and wheat-straw, and the phase I of composting was performed indoor. Compost quality was assessed by the yields obtained in commercial cultivation facilities that reached standards. Three mesocosms were prepared for each strain and were incubated in a climatic chamber at $25^{\circ} \mathrm{C}$ and $90 \%$ of $\mathrm{RH}$ for 15 days in darkness. An uninoculated control (with the compost alone), UIC, was also prepared and incubated under the same conditions.

\subsection{Lignocellulolytic activity assays}

For each mesocosm after incubation at $25^{\circ} \mathrm{C}$ for 15 days, enzyme extraction was performed as previously described by Velazquez et al. (2004) using $10 \mathrm{~g}$ of a composite sample (10 samplings per mesocosm) in a 1-L flask containing $200 \mathrm{~mL}$ of an extraction solution (polyvinylpolypyrolidone $5.7 \mathrm{~g}, \mathrm{CaCl}_{2}, 0.2 \mathrm{M}$, Tween $80,0.05 \%$ ). These samples were subjected to axial shaking for $1 \mathrm{~h}$ at $120 \mathrm{rpm}$ at room temperature. The solids were eliminated by centrifugation at $10,000 \mathrm{~g}$ for $15 \mathrm{~min}$ and filtration through Whatman GF/D filters $(2.7 \mu \mathrm{m})$ and through Whatman GF/C filters $(1.7 \mu \mathrm{m})$. The filtrates of each extract were concentrated overnight at $4{ }^{\circ} \mathrm{C}$ in dialysis tubes ( 15 kda cut-off) using polyethyleneglycol to a final volume of $10 \%$ of initial volume.

Laccase activities were measured by monitoring the oxidation of syringaldazine to quinone $\left(\varepsilon^{\mathrm{M}}=65,000 \mathrm{M}^{-1} \cdot \mathrm{cm}^{-1}\right)$ at $525 \mathrm{~nm}$ in acetate buffer, $0.1 \mathrm{M}, \mathrm{pH} 5$ on a spectrophotometer Biomate 3 (Fischer Bioblock Scientific). One unit per $\mathrm{mL}\left(\mathrm{U} \cdot \mathrm{mL}^{-1}\right.$ ) of laccase activity is defined as the amount of $\mu \mathrm{mol}$ of quinone of syringaldazine produced per min and per $\mathrm{mL}$ of sample at room temperature. Three assays were performed for each enzyme extract.

CM-cellulase activities were measured with carboxymethylcellulose (CMC) and using a simplified methodology adapted from that of Somogyi-Nelson, as previously described [10]. Solution A was composed of $50 \mathrm{~mL}$ of $\mathrm{CuSO}_{4}, 2 \%, \mathrm{Na}_{2} \mathrm{SO}_{4}, 4 \mathrm{~g}$, complemented with $50 \mathrm{~mL}$ of a solution of $\mathrm{Na}_{2} \mathrm{CO}_{3}, 25 \mathrm{~g}, \mathrm{NaHCO}_{3}, 20 \mathrm{~g}$ and sodium potassium tartrate, $25 \mathrm{~g}$, q.s.p. 1 L. Solution $B$ was composed of ammonium-molybdate, $25 \mathrm{~g}, \mathrm{H}_{2} \mathrm{SO}_{4}, 21 \mathrm{~mL}$, and $\mathrm{Na}_{2} \mathrm{HAsO}_{4} 7 \mathrm{H}_{2} \mathrm{O}, 3 \mathrm{~g}$, q.s.p. $450 \mathrm{~mL}$. To measure CMcellulase activity, $0.1 \mathrm{~mL}$ of the extract was incubated at $50{ }^{\circ} \mathrm{C}$ for $1 \mathrm{~h}$ in $0.9 \mathrm{~mL}$ of $50 \mathrm{mM}$ acetate buffer ( $\mathrm{pH} 5.0$ ) with $0.1 \%$ CMC. $1 \mathrm{~mL}$ of solution A was added to $1 \mathrm{~mL}$ of the reaction medium and $1 \mathrm{~mL}$ of distilled water; then the mixture was boiled for $20 \mathrm{~min}$ and cooled down in a cold water bath for $15 \mathrm{~min}$. Then, $1 \mathrm{~mL}$ of solution $\mathrm{B}$ was added and the mixture was left for $50 \mathrm{~min}$ at room temperature and then centrifuged for $2 \mathrm{~min}$ at $10,000 \mathrm{~g}$. The absorption was measured at $870 \mathrm{~nm}$. Dilutions were performed when necessary. For the calibration curves, $1 \mathrm{~mL}$ of solution A was added to $1 \mathrm{~mL}, 750 \mu \mathrm{L}, 500 \mu \mathrm{L}, 250 \mu \mathrm{L}$ of a solution of glucose $(80 \mathrm{mg} / \mathrm{L})$ q.s. $1 \mathrm{~mL}$. Three assays were performed for each enzyme extract.

\subsection{Microbial catabolic profiles via Biolog EcoPlate ${ }^{T M}$}

For each mesocosm after incubation at $25^{\circ} \mathrm{C}$ for 15 days, $10 \mathrm{~g}$ of a composite sample (10 samplings per mesocosm) were vigorously shaken in $100 \mathrm{~mL}$ of a sterilized desorption-solution (sodium pyrophosphate $0.08 \mathrm{~g} / \mathrm{L}$ ) for $1 \mathrm{~h}$ and then brought to a final $\mathrm{OD}=0.001$ at $595 \mathrm{~nm}$. One hundred and fifty microliters of the extracted solution were used to inoculate all 96-wells of a BIOLOG $\odot$ EcoPlate (Biolog, California, USA). One EcoPla$\mathrm{te}^{\mathrm{TM}}$ was used for three mesocosm extracts, since each 96-well plate contained three replicates, each with 31 different carbon sources, one per well, and a water blank. The plates were incubated at $25^{\circ} \mathrm{C}$ for $48 \mathrm{~h}$ and the absorbance was read at $590 \mathrm{~nm}$ using a microplate reader (Tecan, France). To measure the functional diversity (FD), the Shannon's diversity index [11] was calculated [12] from: $\mathrm{FD}=-\Sigma p_{i}\left(\ln p_{i}\right)$, where $p_{i}$ is the ratio of color development of well $i$ to the sum of color development of all positive wells. The microbial activity of each microplate was assessed as average well color development (AWCD) calculated as follows: $\mathrm{AWCD}=\Sigma \mathrm{OD}_{i} / 31$, where $\mathrm{OD}_{i}$ is the optical density for each well.

\subsection{The cross-polarization magic angle spinning ${ }^{13} \mathrm{C}$ nuclear magnetic resonance $\left(C P / M A S{ }^{13} \mathrm{C} N M R\right)$ procedure}

An amount of $10 \mathrm{~g}$ of substrate, sampled as described above, were lyophilized and then ground and sieved $(1 \mathrm{~mm}) . \mathrm{CP} / \mathrm{MAS}{ }^{13} \mathrm{C}$ NMR spectra were obtained on a Bruker DSX $400 \mathrm{MHz}$ spectrophotometer operating at $100.7 \mathrm{MHz}$. Then, samples $(600 \mathrm{mg})$ were spun at $10 \mathrm{KHz}$ at the magic angle. Contact times of $2 \mathrm{~ms}$ were applied with a pulse width of $2.8 \mu \mathrm{s}$ and a recycle delay of $3 \mathrm{~s}$. Chemical shift values were referenced to glycine signal 
(carbonyl C at $176.03 \mathrm{ppm}$ ). The ${ }^{13} \mathrm{C}$ NMR spectra were divided into seven chemical shift regions, according to [13]. Dmfit 2003 software was used to determine the intensity of each chemical shift region [14]. An index of decomposition (HR\#1 Alkyl-C/O-Alkyl-C) was calculated as described before [15]. An aromaticity ratio was also calculated to estimate the degree of humification of organic matter and Alkyl-C/COOH-C ratio HR\#2 was used to assess organic matter transformation using the alkyl chain length of organic acids.

\subsection{Statistical analysis}

The significance of differences (enzyme activities, AWCD and $H^{\prime}$ from Biolog, NMR ratio) between the means of three experiments was tested by non-parametric multiple comparison of Kruskal-Wallis. Each experiment was considered as an independent sample. The optical absorbances of the 30 wells in the ECO plate were subjected to Principal Component Analysis (PCA) after $48 \mathrm{~h}$ of incubation, considering each substrate as a variable. Statistica Vs 6 (StatSoft, Maison-Alfort, France) was used for statistical analysis and a $P$-value $<0.05$ is considered as significant.

\section{Results and discussion}

\subsection{Potential of substrate colonization after spawn incubation using microbial and chemical markers}

Agaricus subrufescens is known to be sensitive to low temperatures, and this particular characteristic is an issue to define adequate storage conditions [16]. Thus, ideal storage conditions, with limited consequences on the ability to colonize cultivation substrate, were still to be defined. Substrate colonization can be assessed by monitoring the extracellular enzyme involved in lignocellulosic material transformation [17]. For these lignocellulolytic activities, the storage of the spawn had an effect on cellulase and laccase activities measured in the composted substrate: after certain storage conditions, these activities were indeed enhanced. Fig. $1 \mathrm{~A}$ and B shows the tendency observed for the $A$. subrufescens strains studied, using the results obtained for strains CA572 and CA 647 for cellulase and laccase activities, respectively. Cellulase activities were significantly higher than in controls (no storage of the spawn) when spawn was stored for 30 days at 10 or $15^{\circ} \mathrm{C}$ (for instance with strain CA 572 in Fig. 1A). Concerning laccase activities, storage had no effect or led to higher laccase activities after spawn incubation at $15^{\circ} \mathrm{C}$ for 30 days (Fig. $1 \mathrm{~B}$ with strain CA 647). In non-inoculated compost, no laccase and cellulase activities were detected. Thus, surprisingly, storage at cold temperatures seems to have a positive effect on the production of the extracellular enzymes involved in the transformation of lignocellulosic substrate during spawn running. The chemical transformation of the substrate was monitored via solid-state NMR of ${ }^{13} \mathrm{C}$ : different ratios $[14,15]$, an aromaticity ratio (AR) and two humification ratios $(\mathrm{HR} 1=\mathrm{Alkyl}-\mathrm{C} / \mathrm{O}-\mathrm{Alkyl}-\mathrm{C}$ and $\mathrm{HR} 2=\mathrm{Alkyl}-$ $\mathrm{C} / \mathrm{COOH}-\mathrm{C}$ ) were calculated from the NMR spectra to determine how storage conditions of the spawn may affect
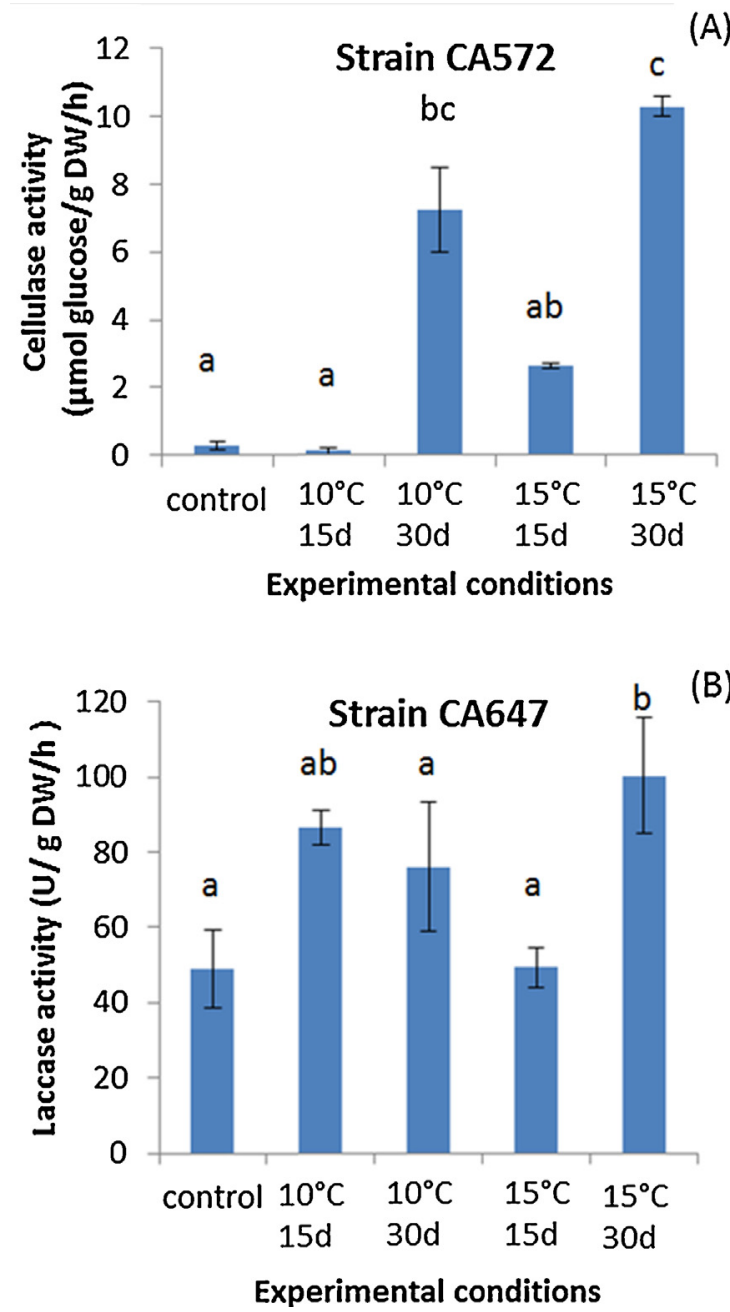

Fig. 1. (Color online.) Trends in cellulase (A) and laccase (B) activities measured in a horse manure- and straw-based compost (here, strains CA 647 and CA 572 as an example). The spawn was previously stored at $15^{\circ} \mathrm{C}$ for 15 days, $15^{\circ} \mathrm{C}$ for 30 days, $10^{\circ} \mathrm{C}$ for 15 days, or $10^{\circ} \mathrm{C}$ for 30 days or not stored (C) and then used for inoculation (incubation was then performed at $25^{\circ} \mathrm{C}$ for 15 days). The letters define the mean values, which are statistically different from each other according to the multiple comparison of Kruskal-Wallis (Dunn procedure).

the capacity of transformation of the substrate. For AR, when an effect was observed, it was always a higher ratio in the case of substrate colonized by spawn previously stored at 10 or $15^{\circ} \mathrm{C}$ than in control (Table 1 ). The same tendency was observed for HR1. Higher values in both AR and HR1 indicate that the recalcitrant fraction of organic matter (linked to alkyl-C and aromatic- $\mathrm{C}$ signals and thus assigned to lipids and phenolic compounds) accumulated in the substrate, while O-Alkyl-C signal, assigned to polysaccharides, decreased. These results clearly indicate that the easily biodegradable fraction of organic matter, i.e. mainly polysaccharides, is more effectively transformed in the substrate inoculated with spawn previously stored at 10 or $15{ }^{\circ} \mathrm{C}$. Thus, our results obtained with solid-state NMR of ${ }^{13} \mathrm{C}$ corroborated those found with lignocellulolytic activities, both microbial and chemical markers indicating that 
Table 1

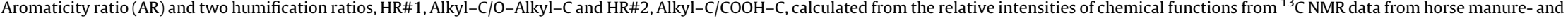

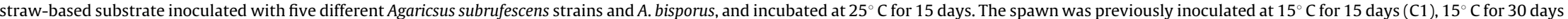
(C2), $10^{\circ} \mathrm{C}$ for 15 days (C3) or $10^{\circ} \mathrm{C}$ for 30 days (C4) or not (C).

\begin{tabular}{|c|c|c|c|c|c|c|c|c|c|c|c|c|c|c|c|c|c|c|}
\hline \multirow[b]{3}{*}{ AR } & \multicolumn{18}{|l|}{ Strains } \\
\hline & \multicolumn{3}{|l|}{ Bs 527} & \multicolumn{3}{|l|}{ CA 454} & \multicolumn{3}{|l|}{ CA 560} & \multicolumn{3}{|l|}{ CA 572} & \multicolumn{3}{|l|}{ CA 646} & \multicolumn{3}{|l|}{ CA 647} \\
\hline & & & & & & & & & & & & & & & & & & \\
\hline C & 0.204 & \pm 0.011 & $a b$ & 0.166 & \pm 0.013 & $a b$ & 0.196 & \pm 0.019 & b & 0.155 & \pm 0.007 & a & 0.170 & \pm 0.017 & a & 0.162 & \pm 0.007 & $\mathrm{a}$ \\
\hline C1 & 0.200 & \pm 0.005 & $a b$ & 0.158 & \pm 0.004 & $\mathrm{a}$ & 0.200 & \pm 0.013 & b & 0.191 & \pm 0.020 & b & 0.189 & \pm 0.014 & $\mathrm{a}$ & 0.195 & \pm 0.004 & b \\
\hline C2 & 0.196 & \pm 0.005 & a & 0.162 & \pm 0.007 & $a b$ & 0.183 & \pm 0.012 & $a b$ & 0.189 & \pm 0.005 & b & 0.186 & \pm 0.005 & a & 0.179 & \pm 0.011 & $a b$ \\
\hline C3 & 0.200 & \pm 0.006 & $a b$ & 0.202 & \pm 0.007 & b & 0.175 & \pm 0.006 & $\mathrm{a}$ & 0.176 & \pm 0.006 & $a b$ & 0.182 & \pm 0.012 & $\mathrm{a}$ & 0.159 & \pm 0.033 & a \\
\hline C4 & 0.208 & \pm 0.004 & $\mathrm{~b}$ & 0.178 & \pm 0.029 & $a b$ & 0.178 & \pm 0.008 & $a b$ & 0.185 & \pm 0.010 & $\mathrm{~b}$ & 0.180 & \pm 0.014 & $\mathrm{a}$ & 0.187 & \pm 0.005 & $a b$ \\
\hline \multicolumn{19}{|c|}{ HR1 } \\
\hline C & 0.413 & \pm 0.017 & c & 0.209 & \pm 0.011 & & 0.407 & \pm 0.060 & a & 0.302 & \pm 0.011 & a & 0.370 & \pm 0.012 & a & 0.361 & \pm 0.062 & $\mathrm{a}$ \\
\hline $\mathrm{C} 1$ & 0.365 & \pm 0.009 & $a b$ & 0.185 & \pm 0.011 & & 0.344 & \pm 0.035 & $\mathrm{a}$ & 0.382 & \pm 0.011 & bc & 0.348 & \pm 0.043 & $\mathrm{a}$ & 0.380 & \pm 0.017 & a \\
\hline $\mathrm{C} 2$ & 0.336 & \pm 0.037 & a & 0.224 & \pm 0.046 & & 0.349 & \pm 0.024 & $\mathrm{a}$ & 0.375 & \pm 0.018 & $a b c$ & 0.407 & \pm 0.075 & $\mathrm{a}$ & 0.372 & \pm 0.036 & a \\
\hline C3 & 0.374 & \pm 0.020 & $a b c$ & 0.352 & \pm 0.044 & & 0.357 & \pm 0.032 & $\mathrm{a}$ & 0.323 & \pm 0.028 & $a b$ & 0.399 & \pm 0.026 & $\mathrm{a}$ & 0.314 & \pm 0.058 & a \\
\hline C4 & 0.404 & \pm 0.017 & bc & 0.331 & \pm 0.052 & & 0.337 & \pm 0.009 & $\mathrm{a}$ & 0.404 & \pm 0.034 & c & 0.355 & \pm 0.064 & $\mathrm{a}$ & 0.395 & \pm 0.064 & $\mathrm{a}$ \\
\hline \multicolumn{19}{|c|}{ HR2 } \\
\hline C & 2.856 & \pm 0.056 & $a b$ & 1.121 & \pm 0.043 & $\mathrm{a}$ & 2.122 & \pm 0.109 & $\mathrm{a}$ & 2.051 & \pm 0.207 & a & 2.220 & \pm 0.222 & a & 1.930 & \pm 0.136 & $\mathrm{a}$ \\
\hline $\mathrm{C} 1$ & 2.819 & \pm 0.278 & $a b$ & 1.720 & \pm 0.297 & $a b$ & 2.450 & \pm 0.116 & b & 2.409 & \pm 0.153 & b & 2.454 & \pm 0.144 & a & 2.602 & \pm 0.022 & b \\
\hline C2 & 2.716 & \pm 0.105 & a & 1.928 & \pm 0.125 & $a b$ & 2.263 & \pm 0.046 & $a b$ & 2.420 & \pm 0.231 & b & 2.359 & \pm 0.243 & a & 2.592 & \pm 0.197 & b \\
\hline C3 & 2.911 & \pm 0.122 & $a b$ & 2.695 & \pm 0.054 & $\mathrm{~b}$ & 2.427 & \pm 0.292 & $a b$ & 2.082 & \pm 0.080 & $a b$ & 2.113 & \pm 0.311 & $\mathrm{a}$ & 2.437 & \pm 0.381 & $a b$ \\
\hline C4 & 2.973 & \pm 0.118 & b & 2.541 & \pm 0.360 & b & 2.125 & \pm 0.132 & $\mathrm{a}$ & 2.178 & \pm 0.209 & $a b$ & 2.199 & \pm 0.359 & $\mathrm{a}$ & 2.414 & \pm 0.137 & $a b$ \\
\hline
\end{tabular}

The different letters indicate when values differ significantly according to the Kruskal-Wallis test and Dunn's procedure for multiple comparisons of means $(P<0.05)$. 
organic matter is actively transformed when spawn is previously stored. For HR2, a higher ratio in substrate inoculated with pre-incubated spawn than in control shows that long alkyl chain acids were predominantly observed. These molecules can be linked to phospholipids from cell membranes [18] and this suggests that fungal biomass may be more extensively produced in solid-state fermentation under these conditions, i.e. when the inoculum has been previously stored at 10 or $15^{\circ} \mathrm{C}$ for two or four weeks. Spawn storage at 10 or $15^{\circ} \mathrm{C}$ seems to enhance the potential for colonization of the culture substrate during spawn running, as described by both microbial and chemical markers used here. This can also be linked with the efficient polysaccharide transformation shown by the increase in both the AR and HR1 ratios.

A. subrufescens grows at higher optimal temperatures than A. bisporus: for instance in previous studies [19], the authors found that optimal temperatures for mycelial growth was around $30^{\circ} \mathrm{C}$, depending on the strains studied. De Mendoca et al. [16] reported optimal temperatures ranging from 25 to $28^{\circ} \mathrm{C}$ and Llarena et al. [20] optimal temperatures varying from 26 to $30^{\circ} \mathrm{C}$, with a similar range of variation for cultivars and wild strains. Long-time storage at low temperatures such as $4{ }^{\circ} \mathrm{C}$ is known to be lethal for $A$. subrufescens [21]. Mycelial growth rate decreased gradually over storage time at $4{ }^{\circ} \mathrm{C}$ of spawn on sorghum grains used for long-term storage of genetic resources [22]. Here, we found that storage at 10 or $15^{\circ} \mathrm{C}$ for a period as long as 30 days did not strongly affect the potential of different $A$. subrufescens strains in their ability of early colonization and transformation of the compost used as cultivation substrate during the spawn running period.

3.2. Changes in functional diversity of microbial communities from the substrate inoculated with spawn previously stored at 10 or $15^{\circ} \mathrm{C}$

To thoroughly investigate the consequences of mycelium storage on $A$. subrufescens ability to colonize compost and how it may change its biotic environment, the diversity of microbial communities of the substrate was also considered via their functional structure. Ecoplates are known to focus on the functional diversity of the bacterial communities since the reduction of tetrazolium dye cannot be accomplished by fungi $[23,24]$. Thus, the Agaricus strain, which colonizes the culture substrate, is not supposed to be involved in the catabolic potential measured here. Global microbial activity was measured by Average Well Color Development (AWCD) and functional diversity via the Shannon-Weaver Index, $H^{\prime}[11,12]$. As for lignocellulolytic activities, a similar tendency was observed for all the A. subrufescens under study and Fig. 2A and $B$ shows the results obtained with strains CA 454 and 647 as an example. In most of the treatments, AWCD was the same as in control. When AWCD varied from the control, higher values were observed whatever the temperature of storage considered (Fig. 2A). For functional diversity characterized by $H^{\prime}$, the same result was observed: a higher $H^{\prime}$ value was found when spawns were stored at $10^{\circ} \mathrm{C}$ or $15^{\circ} \mathrm{C}$ than in control (Fig. 2B). Thus,
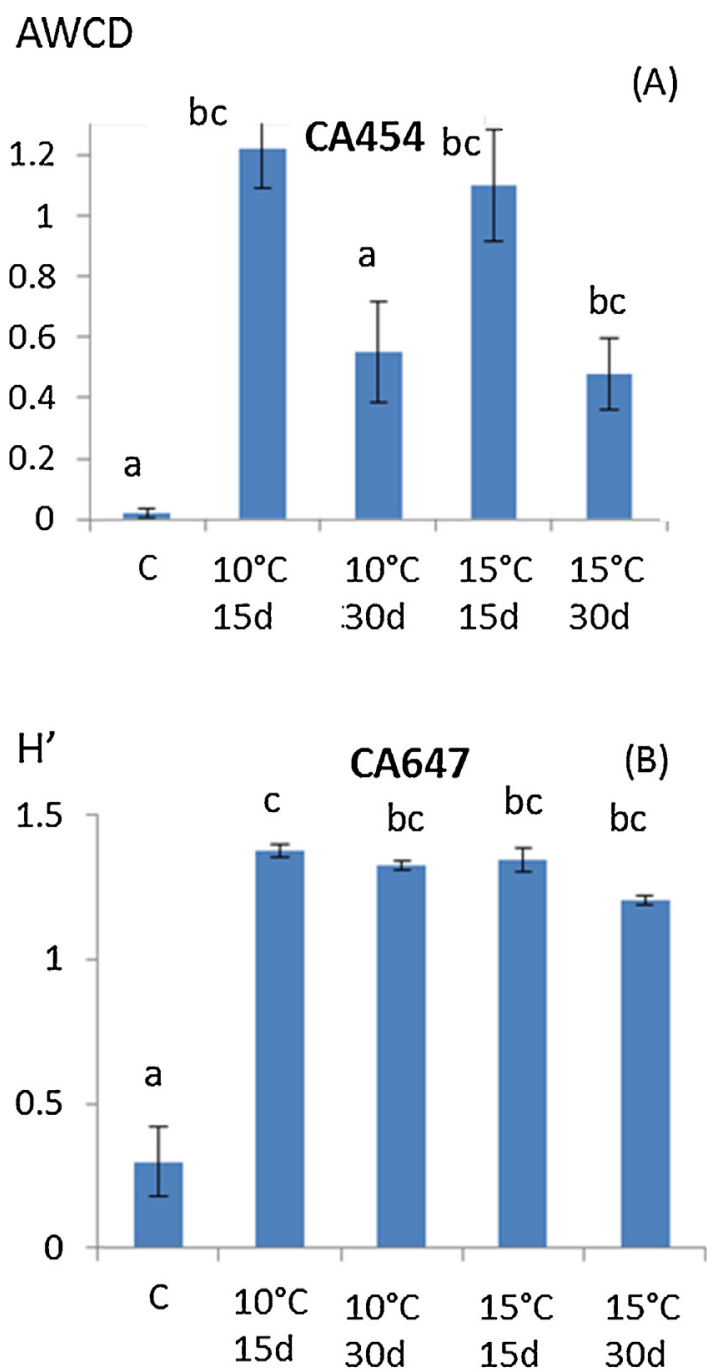

Fig. 2. (Color online.) Trends in (A) AWCD (Average Well Color Development) and (B) Shannon-Weaver index, $H^{\prime}$, based on Ecoplate data after $48 \mathrm{~h}$ of incubation of the microbial extract from a horse manure, and straw-based compost (here strains CA 454 and CA 647 as an example). The spawn was previously stored at $15^{\circ} \mathrm{C}$ for 15 days, $15{ }^{\circ} \mathrm{C}$ for 30 days, $10^{\circ} \mathrm{C}$ for 15 days or $10^{\circ} \mathrm{C}$ for 30 days or not. The letters define the mean values, which are statistically different from each other according to the multiple comparison of Kruskal-Wallis (Dunn procedure).

storage of the spawn had probably an effect on A. subrufescens mycelium, which consequently influenced the microbial communities during mycelial colonization of compost, by enhancing both their global catabolic activity - and thus their potential to transform the substrate - and their biodiversity. Moreover, the high diversity of microbial communities of the substrate is of major importance in the selectivity of the mushroom culture substrate, since it prevents the colonization of potential antagonists [25]. Fig. 3 shows the result of PCA analysis using optical densities of all the substrates used as variables. Axes F1 and F2 accounted for 59.39 and 10.42\% of the variance, respectively. This figure shows that the temperature used for storage $\left(10\right.$ or $15^{\circ} \mathrm{C}$ ) did not globally 


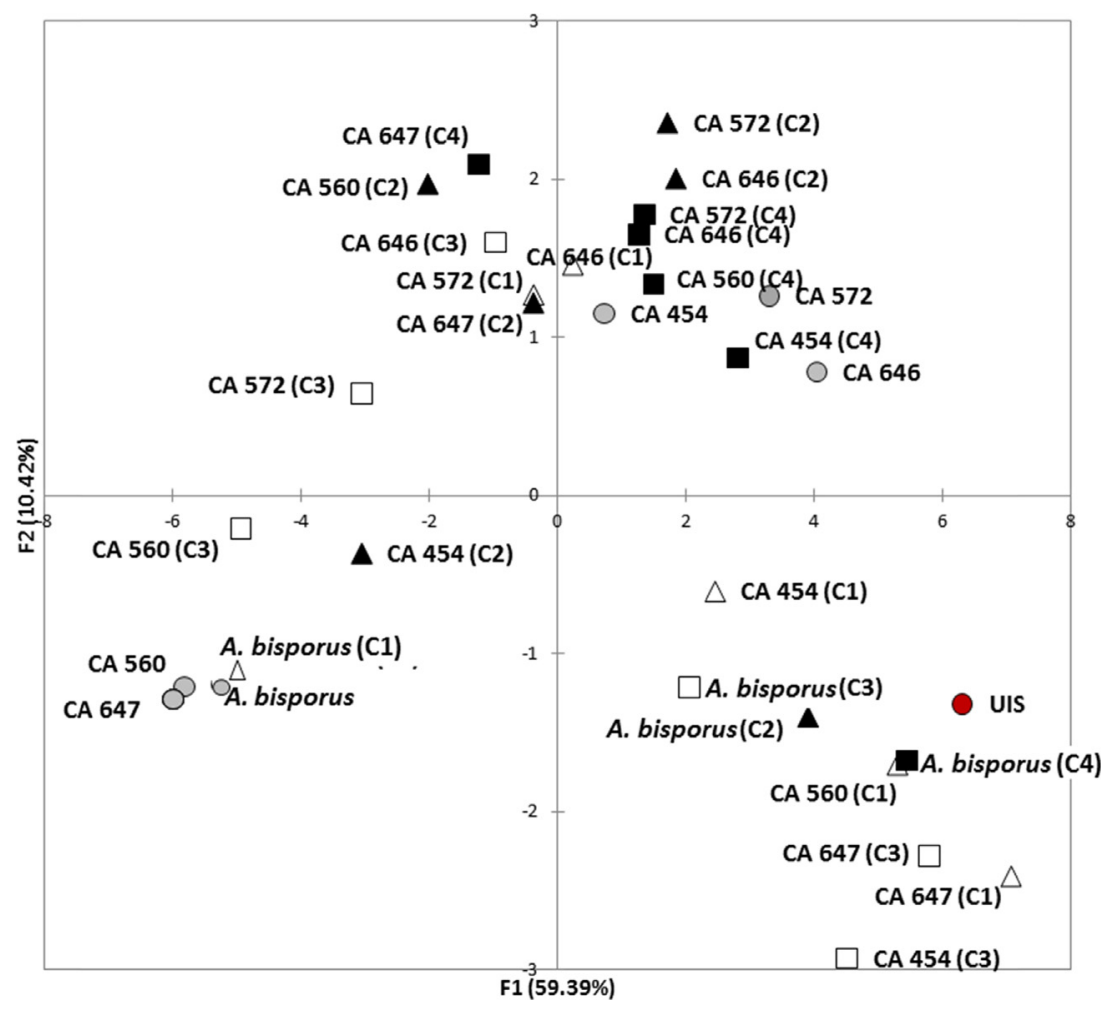

Fig. 3. (Color online.) PCA (based on Pearson's correlation) performed using OD at $48 \mathrm{~h}$ of each Ecoplate carbon source ( $n=30$ ) as variables. The two first factors (F1 + F2) accounted for 72\% of total variance. UIS: Un-Inoculated substrate, horse manure- and straw-based compost inoculated with Agaricus bisporus (strain Bs527) or five strains of $A$. subrufescens, and incubated at $25^{\circ} \mathrm{C}$ for 15 days. The spawn was previously stored at $15{ }^{\circ} \mathrm{C}$ for 15 days ( $\mathrm{C} 1, \Delta$ ), $15^{\circ} \mathrm{C}$ for 30 days $(\mathrm{C} 2, \mathbf{A}), 10^{\circ} \mathrm{C}$ for 15 days $(\mathrm{C} 3, \square)$ or $10^{\circ} \mathrm{C}$ for 30 days $(\mathrm{C} 4 \square)$ or not $(\mathrm{C}, \mathrm{O})$.

affect microbial catabolic diversity, since the projections were not clearly differentiated on the PCA (squares vs triangles). On the other hand, the time of storage (15 or 30 days) influenced this diversity (black $v s$ white) mainly according to axis F2, as observed for strains CA647 and CA560, and to a lesser extent according to F1, for strains CA572 and CA646. PCA was used to give additional information about how the functional diversity of these communities varied. Though the effects of both time and temperature of storage were observed, the more drastic conditions, i.e. $10^{\circ} \mathrm{C}$ and 30 days, did not lead to a strong variation in the diversity structure of substrate microbial communities according to the PCA. Colonization of the substrate by the mycelium of $A$. subrufescens may have modified the associated microbial communities because of microbial interactions, including competition for nutrients or production of antagonistic metabolites. Here, we found that the diversity index, $H^{\prime}$, remained constant or was even higher after spawn storage and PCA added complementary information by indicating that for certain strain, this functional diversity actually changed compared to control.

A. subrufescens can be considered as an important edible mushroom because of its medicinal and culinary properties, which culture conditions still have to be precisely described. In our previous study [17], we found that a horse manure and wheat-straw-based compost produced under physicochemical conditions commonly used for the button mushroom A. bisporus was suitable for this tropical Agaricus species. Here, our investigations focused on storage conditions of the spawn, which is a very important parameter to favor mushroom cultivation. Our study revealed that storage conditions of the spawn for up to 30 days, at relatively low temperatures for this fungus, did not further affect substrate colonization by this species. Storage under certain conditions even improved its potential of colonization and this potential seems to be strain dependent. These results are encouraging, since they demonstrate that these storage conditions at 10 to $15^{\circ} \mathrm{C}$ cannot be ruled out in the cultivation process. However, further studies should determine whether these storage conditions have effects on crop yields or mushroom quality in order to confirm these first findings.

\section{Acknowledgements}

This work was supported by the Agence Nationale de la Recherche (French Government founds), project ANR-09BLAN-0391. We are very grateful to Mrs Marjorie Sweetko for her very helpful assistance in English language.

\section{References}

[1] R.W. Kerrigan, Agaricus subrufescens, a cultivated edible and medicinal mushroom, and its synonyms, Mycologia 97 (2005) 12-24.

[2] G. Mata, J.-M. Savoie, Preservation of Agaricus subrufescens strains at low temperature by using cultures on sorghum grains, Rev. Iberoamericana Micol. 30 (2013) 96-102. 
[3] T. Stijve, M.A. de Amazonas, V. Giller, Characterization of flavour and taste compounds in Agaricus blazei Murill sensu Heinem., the cultivated almond mushroom, Austr. Mycol. 22 (2003) 116-122.

[4] F.M. Jumes, D. Lugarini, A.L. Pereira, A. De Oliveira, C.O. Ade, G.A. Linde J.S. Do Valle, N.B. Colauto, A. Acco, Effects of Agaricus brasiliensis mushroom in Walker-256 tumor-bearing rats, Can. J. Physiol. Pharm. 85 (2010) 21-27.

[5] M.L. Largeteau, R.C. Llarena-Hernandez, C. Regnault-Roger, J.M. Savoie, The medicinal Agaricus mushroom cultivated in Brazil: biology, cultivation and non-medicinal valorization, Appl. Microbiol. Biot. 92 (2011) 897-907.

[6] D.P. Mamiro, D.J. Royse, The influence of spawn type and strain on yield, size and mushroom solids content of Agaricus bisporus produced on non-composted and spent mushroom compost, Bioresour. Technol. 99 (2008) 3205-3212

[7] D.J. Royse, W. Chalupa, Effects of spawn, supplement and phase II compost additions and time of re-casing second break compost on mushroom (Agaricus bisporus) yield and biological efficiency, Bioresour. Technol. 100 (2009) 5277-5282.

[8] P. Ruiz-Rodríguez, I. Polonia, C. Soler-Rivas, H.J. Wichers, Ligninolytic enzymes activities of oyster mushrooms cultivated on OMW (olive mill waste) supplemented media, spawn and substrates, Int. Biodeter. Biodegr. 65 (2011) 285-293.

[9] M. Foulongne-Oriol, C. Spataro, M. Moinard, D. Cabannes, P. Callac, J.M Savoie, Development of polymorphic microsatellite markers issued from pyrosequencing technology for the medicinal mushroom Agaricus subrufescens, FEMS Microbiol. Lett. 334 (2012) 119-126.

[10] A.M. Farnet, L. Qasemian, D. Guiral, E. Ferré, A modified method based on arsenomolybdate complex to quantify cellulase activities: application to litters, Pedobiologia 53 (2010) 159-160.

[11] C.E. Shannon, T. Weaver, A mathematical theory for communication, Bell Syst. Tech. J. 27 (1948) 379-423 (\& 623-656).

[12] J.C. Zack, M.R. Willig, D. Moorhead, L. Howard, G. Wildman, Functional diversity of microbial communities: a quantitative approach, Soil Biol. Biochem. 26 (1994) 1101-1108.

[13] F. Ziarelli, Applications et développements des méthodes de résonance magnétique nucléaire haute résolution à l'état solide pour les matériaux organiques et inorganiques, (Thèse de doctorat), université AixMarseille-I, 2004, p. 110.

[14] D. Massiot, F. Fayon, M. Capron, I. King, S. Le Calve, B. Alonso, J.O. Durand B. Bujoli, Z.H. Gan, G. Hoatson, Modelling one- and two-dimensional solid-state NMR spectra, Magn. Reson. Chem. 40 (2002) 70-76.
[15] J. Baldock, J.M. Oades, P.N. Nelson, T.M. Skene, A. Golchin, P. Clarke, Assessing the extent of decomposition of natural organic materials using solid-state C-13 NMR spectroscopy, Aust. J. Soil Res. 49 (1997) 1061-1083.

[16] CT Agaricus blazei cultivation for a living in Brazil, M. De Mendoca, M Kasuya, A. Cadorin, J.A. Vieira (Eds.), Mushroom growers' handbook, 2005, pp. 208-218.

[17] A.M. Farnet, L. Qasemian, F. Peter-Valence, J.M. Savoie, F. Ruaudel, E. Ferré, Capacity for colonisation and degradation of horse manure and wheat-straw-based compost by different strains of Agaricus subrufescens during the first two weeks of cultivation, Bioresour. Technol. 131 (2013) 266-273

[18] F. Peter-Valence, C. Llarena-Hernandez, M. Largeteau, J.M. Savoie, F. Ruaudel, F. Ziarelli, E. Ferré, A.M. Farnet, Chemical characterization of the biomass of edible medicinal mushroom Agaricus subrufescens, via solid-state ${ }^{13} \mathrm{C}$ NMR, J. Agr. Food Chem. 59 (2011) 8939-8943.

[19] N.B. Colauto, P.M. Aizono, L.R.M. Carvalho, L.D. Paccola-Meirelles, G.A. Linde, Temperature and $\mathrm{pH}$ conditions for mycelial growth of Agaricus brasiliensis on axenic cultivation, Cienca Agrária 29 (2008) 307-312.

[20] R.C. Llarena-Hernandez, M.L. Largeteau, A.M. Farnet, M. FoulogneOriol, N. Ferrer, C. Regnault-Roger, J.M. Savoie, Potential of European wild strains of Agaricus subrufescens for productivity and quality on wheat-straw based compost, World J. Microb. Biot. 29 (2013) $1243-1253$

[21] X. Zou, Effect of Zn supplementation on the growth, amino acid composition, polysaccharide yields and anti-tumour activity of Agaricus brasiliensis, World J. Microbiol. Biotechnol. 21 (2005) 261-264.

[22] G. Mata, J.M. Savoie, Preservation of Agaricus subrufescens strains at low temperature by using cultures on sorghum grains, Rev. Iberoamerican Micol. (2013), http://dx.doi.org/10.1016/j.riam.2012.10.002.

[23] H. Heuer, K. Smalla, Evaluation of community-level catabolic profiling using BIOLOG GN microplates to study microbial community changes in potato phyllosphere, J. Microbiol. Meth. 32 (1997) 49-61.

[24] J. Preston-Mafham, L. Boddy, P.F. Randerson, Analysis of microbial community functional diversity using sole-carbon-source utilization profiles: a critique, FEMS Microbiol. Ecol. 42 (2002) 1-14.

[25] M.A. Velázquez-Cedeño, A.M. Farnet, G. Mata, J.M. Savoie, Role of Bacillus spp. in antagonism between Pleurotus ostreatus and Trichoderma harzianum in heat-treated wheat-straw substrates, Bioresour. Technol. 99 (2008) 6966-6973. 